\title{
Stylistic Analysis on William Blake's The Little Boy Lost
}

\author{
Olyvia Vita Ardhani \\ English Letter Department, Universitas Sanata Dharma Yogyakarta, Indonesia \\ olyviavitaa19@gmail.com
}

\begin{abstract}
This research presented the stylistic analysis of a poem by William Blake, The Little Boy Lost. The poem was chosen as it becomes Blake's one of well-known poems in his Song of Innocence. Moreover, this poem uses simple structure and dictions, but it conveys a profound meaning. This research aimed: (1) to discover how the language level in the poem used and (2) to find out the interpretation of the poem. The stylistic analysis aimed at observing the meaning of either literary or non-literary text by the language device used. The researcher conducted a data population method in analyzing the poem. There were four language levels to achieve the goal; they were phonological, graphological, lexical, and syntactic level (Verdonk: 2002). In the phonological level, assonance, consonance, and alliteration were used to emphasize important words. In the graphological level, the comma in the last line of stanza 1 is prominent to distinguish the different speakers. In the lexical level, metaphor was used to voice the little boy's hopes to find enlightenment to get out of his difficulties. Meanwhile, symbolism conveys a deeper meaning than the literal meaning. In the syntactic level, the tenses switching used to emphasize the different speakers and the comma in the graphological level; and the word repetition used to create the little boy's sense of innocence.
\end{abstract}

Keywords: language feature; poem; stylistic

\section{A. Introduction}

Literary work is a piece of art that is expressed in the form of writing. It is imaginative and creative writing. A literary work could be in the form of a poem, drama, prose, or novel (Febriani, et al. 2020; Handayani, et al. 2020). The authors express what is going on in their life, also deliver a message for the readers through their writing. Therefore, language is needed to fulfil those purposes. Literary works have a different linguistic feature than the standard language because they have different purposes. According to $\mathrm{UI}^{\mathrm{a}}$ (2014), standard language usages carry the purpose of communication, while literary work has no purpose as such.

Poem is a language that means more than it. According to Gill (1995), poems are not like ordinary speech or writing, they are specially made objects in words. One of exciting thing in the poem is its style. According to Leech and Short (2007), style is how the language is used in a given context, by given person, for a given person. It is supported by Tezcan (2014) that style is generally accepted as the linguistics habit of the author and stylistics is the study of style within a text. Barry (2002) mentions that stylistics is a critical approach that uses linguistics science's method and findings to analyse a literary text. Stylistic analysis 
Iadila $\cdot$ Iournal of Dovelonment and Innovation in I anouago and I.itorature F.duration

Publisher: Yayasan Karinosseff Muda Indonesia
F.ISSN $\cdot 2773.3-690$ ก

P-ISSN: 2745-9578

Volume: 1 Number 2, 2020

Page: $175-181$

focuses on the author's language in a literary text. It provides the readers with valuable data for more objective analysis of literary work. Therefore, stylistics analysis is needed to interpret the literary work.

Leech and Short (2007) mention that distinguishing the level of language is necessary. Language could be distinguished into four levels; semantics level, syntactic level, phonological level, and graphological level. Semantics level deals with the meaning of the language, while the syntactic level deals with the sentences' structure. Phonological level deals with speech sound, and the graphological level deals with typographical features of the text. Phonology becomes the sound pattern of the language, and syntax is the roughly speaking, grammatical, and lexical form of language. Furthermore, the syntax is the level of lexico-grammar form which mediates between the levels of sound and meaning. Graphology is the alternative system of realization to phonology.

Previous studies on the same approach have been done before by some scholars. The first study is conducted by Baigy and Zarrinjooee (2014) entitled "Giffordian Post-Pastoral and Loss of Innocence in William Blake's The Little Boy Lost and The Little Boy Found." This research aimed to explore the loss of innocence in Blake's The Little Boy Lost and The Little Boy Found based on Giffordian post-pastoral theory through interpreting three fundamental features. Those three prominent features are the exploitation of natural world parallel and exploitation of hapless children as minorities, the need for culture as nature and vice versa, and the need for consciences to heal consciousness as a source of alienation. This research concludes that The Little Boy Lost indicates the possibility of loss and innocence, which is resulted from cheap children labour and exploitation during the industrialized system as the most valuable things for a business person. Furthermore, The Little Boy Found depicts a possibility of New Jerusalem as equal as the ideal culture as well as God's promises of paradise in heaven for those young, innocent children. This research is similar to the poem that is used to analyse. The dissimilarity lies in the approach of the study; the previous study utilized the Giffordian Post-Pastoral study, which is from a literature perspective; while the present study applies stylistic study, which is from a linguistic perspective.

The second study is a journal article by Mahmood and Jamil (2015) entitled "Stylistics Analysis of Holly Thursday I By William Blake." This research aimed to analyse Blake's Holly Thursday from stylistics perspective along with accommodating to analyse Blake's style in writing poems. According to Mahmood and Jamil (2015), this poem defined the Available at https://ejournal.karinosseff.org/index.php/jadila/ 
Iadila $\cdot$ Iournal of Dovelonment and Innovation in I anouago and I.itorature F.duration

Publisher: Yayasan Karinosseff Muda Indonesia
F.ISSN $\cdot 2773.3-690$ ก

P-ISSN: 2745-9578

Volume: 1 Number 2, 2020

Page: $175-181$

beauty and irony of the church tradition. This research concludes that stylistics analysis of this poem has shown that there is dissimilarity between poetic and non-poetic language as a means of defining literature. Both present and previous studies use stylistic study to analyse the poem and the same author; however, the poem used is different. The present study used The Little Boy Lost, while the previous study used Holly Thursday.

These related studies motivate the researcher to analyse Blake' The Little Boy Lost. This research aims to discover how the poem's language level is used and to find out the interpretation of the poem through its language level. Blake was the most independent and original romantic poet in the 18th century. Mostly, he employs plain and direct language in his poems. He does not like and believe in abstract things; therefore, he uses vivid visual images. On the other hand, he also uses many symbolisms in his poems. Thus, this research will give the readers an idea to understand the poem deeper and more objective because the analysis is not only based on the readers' assumption only.

\section{B. Research Methodology}

Stylistic approach is applied in this research. It concerns with the language style in literary text or non-literary text. Gibbons and Whiteley (2018) add that stylistic is an integrated study of language and literature. In analyzing literary text, there are four language level according to Verdonk (2002), they are phonological, graphological, lexical, and syntactic level. In the phonological level, assonance, consonance, and alliteration are analyzed. In the graphological level, comma is observed, and in lexical level the use of metaphor and symbolism is analyzed.

Moreover, in the syntactic level, there are tenses and word repetition are observed. The data for this research is taken from written literary text, which are the whole poems by William Blake titled The Little Boy Lost. The gathered data is analyzed through four language levels; phonological, graphological, lexical and syntactic level as mentioned above. Thus, the interpretation of the poem could be revealed based on the finding on the language levels.

This research conducted a data population method. According to Best and Khan (2014: 11), data population method used in study when the data have one characteristic in common. The data in this research is the language features in Blake's The Little Boy Lost. The population was in the form of the literary text taken from the whole parts of the poems. The way collecting the data was by reading the whole poem, then identifies the language features 
Iadila $\cdot$ Iournal of Dovelonment and Innovation in I anouage and I.itorature Fiducation

Publisher: Yayasan Karinosseff Muda Indonesia
F.ISSN $\cdot 2773.3-690$ ก

P-ISSN: 2745-9578

Volume: 1 Number 2, 2020

Page: 175-181

found in each level to answer the first research question. Further, the researcher figured out the interpretation of the poem through its language features.

\section{Results and Discussion}

\section{Results}

This part shows the result of the finding. In poetic language, sound patterns could be found in alliteration, assonance, and consonance (Wales, 2011). The table below displays the summary of assonance, consonance, and alliteration in the phonological level.

Table 1. Summary of Phonological Features in the Data

\begin{tabular}{|c|c|c|c|c|}
\hline \multirow{2}{*}{ Stanza } & \multirow{2}{*}{ Line } & \multicolumn{3}{|c|}{ Phonological Features } \\
\cline { 3 - 5 } & & Assonance & Consonance & Alliteration \\
\hline 1 & 1 & father, father & father, father & father, father \\
\hline & 2 & o, so & not, fast & - \\
\hline & 3 & speak, speak & speak, speak & speak, speak \\
\hline 2 & 1 & - & father, your & - \\
\hline & & was, was & was, was & was, was \\
\hline & 2 & - & - & the, there \\
\hline & 3 & deep, weep & deep, weep & deep, did \\
\hline
\end{tabular}

From the table above, assonance occurs five times in the poem. Assonance is the repetition of the vowel sound. In the line 1 stanza 1 , the sound /a/ is repeated in the word "father" and "father." Moreover, the diphthong /əv/ is repeated in the word "o" and "so" in line 2, stanza 1. There is also a repetition of vowel /i:/ in the word "speak" and "speak" in line 3 stanza 1. Furthermore, in stanza 2, line 1, the sound / $/$ / is repeated in the word "was" and "was," and in the line 3, the sound /i:/ repeated in the word "deep" and "weep".

Another phonological feature is consonance. Consonance is the repetition of the final sound. There are four consonances occur in stanza 1. In the line 1, there is a repetition of the final sound $/ \mathrm{r} /$ in the word "father" \& "father." In the line 2 , the sound $/ \mathrm{t} /$ is repeated in the word "not" and "fast." In the line 3, there are two repetitions of the final sound, sound /k/ in the word "speak" and "speak," and sound /r/ in the word "father" and "your." Consonance 
Iadila $\cdot$ Iournal of Dovelonment and Innovation in I anouage and I iterature Fduration

Publisher: Yayasan Karinosseff Muda Indonesia
F.ISSN $\cdot 2773.3-6900$

P-ISSN: 2745-9578

Volume: 1 Number 2, 2020

Page: 175-181

also occurs two times in stanza 2. In the line 1, the sound /s/ is repeated in the word "was" and "was". Then, the final sound /p/ is repeated in the word "deep" and "weep" in the line 3.

The repetition of the first consonant sound in a line is called alliteration. Alliteration appears two times in stanza 1. The sound /f/ is repeated in the word "father" and "father" in the line 1. Moreover, in the line 3, the sound /s/ in the word "speak" and "speak." Alliteration also appears in stanza 2. In the line 1, the repetition is in the sound /ð/ in the word "the" and "there" and sound /w/ in the word "was" and "was". The repetition of sound /w/ also occurs in the word "was" and "wet". The repetition of sound /d/ in the word "deep" and "did" occur in the line 3.

Table 2. Summary of Graphological Features in the Data

\begin{tabular}{|c|c|c|c|c|}
\hline \multirow{2}{*}{ Stanza } & \multirow{2}{*}{ Line } & \multicolumn{3}{|c|}{ Graphological features } \\
\cline { 3 - 5 } & & Comma & Period & Ampersand \\
\hline 1 & 1 & 2 & - & - \\
\hline & 2 & - & 1 & - \\
\hline & 3 & 1 & - & - \\
\hline 2 & 4 & 1 & - & - \\
\hline & 1 & - & - & - \\
\hline & 2 & - & 1 & - \\
\hline & 3 & 1 & - & - \\
\hline
\end{tabular}

Graphology deals with capitalization and punctuation. Capitalization can be found in every first word in every line. However, there are four commas in stanza 1. Two commas in the line 1 , and a comma in the line 3 , in which both of them lie between words. There is a comma in the end of the line that is found in the line 4 . There is also a period in line 2 , stanza 1. In the stanza 2, there are a comma in the line 2 that occur in the middle of the line and two periods in the line 2 and 4.

The next level of language is the lexical level. There are metaphor and symbolism can be found in this level. The metaphor is in the last line of the poem.

And away the vapour flew. (stanza 2, line 4)

Moreover, there are three symbols in the poem. Those are "the little boy," "father," and "dark." 
Iadila $\cdot$ Iournal of Dovelonment and Innovation in I anouso and I.itorature Fiduration

Publisher: Yayasan Karinosseff Muda Indonesia
F.ISSN $\cdot 2773.3-690$ ก

P-ISSN: 2745-9578

Volume: 1 Number 2, 2020

Page: $175-181$

There are tenses switching and word repetition in the syntactic level. The tenses switching here is from the present tense in the first stanza to the past tense in the second stanza. Furthermore, the word "father" and "speak" are repeated in the poem. "Father" is repeated four times, while "speak" is repeated two times.

\section{Discussion}

Simpson mentions that sound pattering plays a pivotal role in literary discourse in general, and in poetry in particular (2004: 14). From the finding above, Blake applies phonological features for some reasons. Those reasons are (1) to beautify the poem, (2) to give special effect to the reader so that could bring the reader into the poem more in-depth, and (3) to emphasize important words that convey profound meaning. As it is shown in the table that in the words "father" and "speak" could be found alliteration, consonance, and assonance in each word. It means that Blake highlights those words in order to deliver his message.

In the graphology level, Blake uses capital letters in the first word in every line as what McCaskill (1998) said that the first word of sentences must be written in capital letter. On the other hand, there are four commas in stanza 1. However, there is a special comma in the last line of stanza 1 because of its position. This comma lies on the last sentence. It is used because this poem has two speakers, the first speaker is the child, and the second speaker is the narrator. In the first stanza, the speaker is the child, while in the second stanza the speaker is the narrator. Therefore, there is a comma in the last line. The function of this comma is to quote what the child has said, as in the direct speech. Moreover, in stanza 2, Blake also uses ampersand instead of the word "and". It is used to avoid repetition of word "and" because there is also "and" and still in the same sentence in the following line. The word "and" in the poem is not a meaningful word which conveys meaning; it is just a conjunction.

In the lexical level, it can be found metaphor and symbolism. Metaphor can be seen in the last line of the poem.

$$
\text { And away the vapour flew. (stanza 2, line 4) }
$$

Metaphor is a direct comparison between two different things. Here, Blake compares vapour to the bird. Vapour here is not the literal meaning, vapour here means fog. This fog prevents the child from getting out of his difficulties. Usually, fog is dark; therefore, the child hopes to find enlightenment to get out of his difficulties. 
The word "father," "the little boy," and "dark" in the poem convey deep meaning, not just the literal meaning. Here, "Father" symbolizes something greater, God. Furthermore, "the little boy" symbolizes the human soul who lost their way or lost its grip on life. The word "dark" also conveys something more profound than the literal meaning. "Dark" here symbolizes the difficulties that the child should face it alone.

In the syntactic level, there are tenses switching and word repetition. The tenses switching here is from the present tense in the first stanza to the past tense in the second stanza. The second stanza uses past tense to retell what happened to the child, while the first stanza uses the present tense because it is what the child said, in the direct speech.

The word "father" and "speak" are repeated in the poem. Repetition is used to emphasis something important or out of intensity of feeling (Wales, 2011). The word "father" is repeated four times because that father figure in the poem is the figure that the child is really looking for to save his life and lead him. Moreover, the word "speak" is also repeated two times. For the child, he will be saved if the father speaks to him to give him some directions for his life.

From all the finding in language features above, it can be interpreted that this poem is about a human soul who loses his/her way of life when they are in a tough situation of life. They are looking for a figure that can save their lives or help them get out of their cruelties. They feel like their grips of life leave them; however, the truth is they are not left.

\section{Conclusion and Suggestion}

The stylistic analysis, which pays attention to the different language levels is proven to give better understanding of literary text. In the phonological level, Blake uses repetition in alliteration, assonance, and consonance in the same words to emphasize that those words are very prominent. In the graphological level, the comma in the last line of stanza 1 is essential. In the lexical level, the poet uses metaphor and symbolism to create a sense of innocence. In the syntactic level, there is tenses switching and word repetition. In summary, the previous finding reveals that the meaning of the poem is about the human soul who lost their grip of life, and should face their difficulties in life alone, without a figure that can lead them to get out from their difficulties. 
To strengthen this research, there are still many language features that can be applied.

The next researcher is suggested to analyze this poem by applying all the language features so that the interpretation of the poem will be more objective and valid.

\section{References}

Baigy, M. Z, \& Zarrinjooee. B. (2014). Giffordian Post-pastoral and Loss of Innocence in William Blake's the Little Boy Lost and the Little Boy Found. International Journal of Literature and Arts. P. 35-39. doi: 10.11648/j.ijla.20140202.12

Barry, P. (2002). Beginning Theory $\left(2^{\text {nd }}\right.$ ed). Manchaster: Manchaster.

Best, J. W., \& Kahn, J. V. (2014). Research in Education: Pearson New International Edition (Tenth rd.). Essex: Pearson Education Limited.

Erdman, David. V. (1988). The Complete Poetry and Prose of William Blake. New York: Anchor Books.

Febriani, R. B. Satinem., Nurnaningsih., Haryani., Syafryadin, Noermanzah.(2020). Conveying an author's intention to efl readers: The meaning of "The Road Not Taken" by Robert Frost. International Journal of Innovation, Creativity and Change (IJICC), 13(4), 172.

Gibbons, A. \& Whiteley, S. (2018). Contemporary Stylistics Language, Cognition, Interpretation.

Edinburg: Edinburg University Press Ltd.

Gill, Richard. (1995). Mastering English Literature. New York: Palgrave.

Handayani, S., Youlia, L., Febriani, R.B., Syafryadin, S. (2020). The use of digital literature in teaching reading narrative text. Journal of English Teaching, Applied Linguistics And Literatures (JETALL). 3(2), 65-74.

Leech, G. \& M. Short. (2007). Style in Fiction: An Introduction to English Fictional Prose $\left(2^{\text {nd }}\right)$. London: Pearson Education Limited.

Mahmood, R., \& Jamil, A (2015, September). Stylistics Analysis of Holly Thursday I by William Blake. International Journal of English Language and Linguistics Research, 3(6), 46-52.

McCaskill, Mary K. (1998). Grammar, Punctuation, and Capitalization. Virginia: Langley Research Center.

Simpson, Paul. (2004). Stylistics A Resource Book for Students. London: Routledge.

Tezcan, T. (2014). A Stylistic analysis of A Rose for Emily by William Faulkner and its Turkish Translation. Procedia - Social and Behavioral Science 158, 364 - 369.

$\mathrm{UI}^{\mathrm{a}}$, Büsra. (2014). Foregrounded: a comparative stylistic analysis of Their Eyes Were

Watching God and its Turkish translation. Procedia - Social and Behavioral Science $158,37-42$

Verdonk, P. (2002). Stylistics. Oxford: Oxford University Press.

Wales, Katie. (2011). A Dictionary of Stylistics $\left(3^{\text {rd }}\right)$. New York: Routledge. 